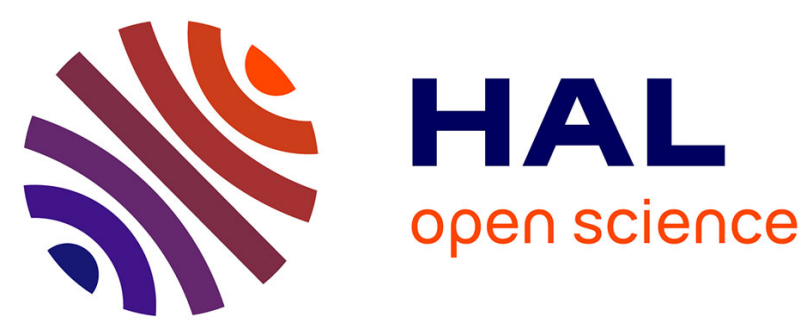

\title{
Chronic toxicity and physiological changes induced in the honey bee by the exposure to fipronil and Bacillus thuringiensis spores alone or combined
}

Maria Tereza Renzi, Marcel Amichot, David Pauron, Sylvie Tchamitchian, Jean-Luc Brunet, Andre Kretzschmar, Stefano Maini, Luc Belzunces

\section{To cite this version:}

Maria Tereza Renzi, Marcel Amichot, David Pauron, Sylvie Tchamitchian, Jean-Luc Brunet, et al.. Chronic toxicity and physiological changes induced in the honey bee by the exposure to fipronil and Bacillus thuringiensis spores alone or combined. Ecotoxicology and Environmental Safety, 2016, 127, pp.205-213. 10.1016/j.ecoenv.2016.01.028 . hal-02630348

\section{HAL Id: hal-02630348 \\ https://hal.inrae.fr/hal-02630348}

Submitted on 27 May 2020

HAL is a multi-disciplinary open access archive for the deposit and dissemination of scientific research documents, whether they are published or not. The documents may come from teaching and research institutions in France or abroad, or from public or private research centers.
L'archive ouverte pluridisciplinaire HAL, est destinée au dépôt et à la diffusion de documents scientifiques de niveau recherche, publiés ou non, émanant des établissements d'enseignement et de recherche français ou étrangers, des laboratoires publics ou privés. 


\title{
Chronic toxicity and physiological changes induced in the honey bee by the exposure to fipronil and Bacillus thuringiensis spores alone or combined
}

\author{
Maria Teresa Renzi ${ }^{\mathrm{a}, \mathrm{b}}$, Marcel Amichot ${ }^{\mathrm{c}}$, David Pauron ${ }^{\mathrm{c}}$, Sylvie Tchamitchian ${ }^{\mathrm{a}}$, \\ Jean-Luc Brunet ${ }^{\mathrm{a}}$, André Kretzschmar ${ }^{\mathrm{d}}$, Stefano Maini ${ }^{\mathrm{b}}$, Luc P. Belzunces ${ }^{\mathrm{a}, *}$ \\ a INRA, Laboratoire de Toxicologie Environnementale, UR 406 AEE, CS 40509, 84914 Avignon Cedex 9, France \\ b Dipartimento di Scienze Agrarie, Università di Bologna, Viale G. Fanin, 42, 40127 Bologna, Italy \\ ${ }^{\mathrm{c}}$ INRA, Université Nice Sophia Antipolis, CNRS, UMR 1355-7254 Institut Sophia Agrobiotech, 06900 Sophia Antipolis, France \\ d INRA, UR Biostatistiques et Processus Spatiaux, CS 40509, 84914 Avignon Cedex 9, France
}

Keywords:

Honey bees

Bacillus thuringiensis

Fipronil

Physiological modulations

\begin{abstract}
A B S T R A C T
In the agricultural environment, honey bees may be exposed to combinations of pesticides. Until now, the effects of these combinations on honey bee health have been poorly investigated. In this study, we assessed the impacts of biological and chemical insecticides, combining low dietary concentrations of Bacillus thuringiensis $(\mathrm{Bt})$ spores (100 and $1000 \mu \mathrm{g} / \mathrm{L})$ with the chemical insecticide fipronil $(1 \mu \mathrm{g} / \mathrm{L})$. In order to assess the possible effects of Cry toxins, the Bt kurstaki strain (Btk) was compared with a Bt strain devoid of toxin-encoding plasmids $\left(\mathrm{Bt} \mathrm{Cry}^{-}\right)$. The oral exposure to fipronil and Bt spores from both strains for 10 days did not elicit significant effects on the feeding behavior and survival after 25 days. Local and systemic physiological effects were investigated by measuring the activities of enzymes involved in the intermediary and detoxication metabolisms at two sampling dates (day 10 and day 20). Attention was focused on head and midgut glutathione-S-transferase (GST), midgut alkaline phosphatase (ALP), abdomen glyceraldehyde-3-phosphate dehydrogenase (GAPD) and glucose-6-phosphate dehydrogenase (G6PD). We found that Bt $\mathrm{Cry}^{-}$and Btk spores induced physiological modifications by differentially modulating enzyme activities. Fipronil influenced the enzyme activities differently at days 10 and 20 and, when combined with Bt spores, elicited modulations of some spore-induced physiological responses. These results show that an apparent absence of toxicity may hide physiological disruptions that could be potentially damaging for the bees, especially in the case of combined exposures to other environmental stressors.
\end{abstract}

\section{Introduction}

The populations of domestic honey bees (Apis mellifera L.) have been shown to be declining (vanEngelsdorp et al., 2008; Potts et al., 2010; Van Der Zee et al., 2012). Among the various risk factors responsible for this decline, contamination by plant protection products has been considered to play a significant role (Maini et al., 2010; Krupke et al., 2012). In field conditions, honey bees are likely to be exposed to multiple substances, either sequentially or concomitantly, and several studies have highlighted the necessity to better investigate the effects of pesticide associations, especially at low concentrations (Mullin et al., 2010; Krupke et al., 2012). As an example, significant synergistic effects

\footnotetext{
* Corresponding author.

E-mail address: luc.belzunces@avignon.inra.fr (L.P. Belzunces).
}

have been extensively demonstrated between pyrethroids, or neonicotinoids, and EBI fungicides (Colin and Belzunces, 1992, Iwasa et al., 2004). However, the impact of pesticide combinations at lethal and sublethal levels are still poorly investigated for other substances. In this study, we considered the possible combined exposure of honey bees to a biological insecticide, Bacillus thuringiensis (Bt) and a chemical insecticide, fipronil, at low concentrations, consistent with the application rate of Bt-based products and with possible environmental contaminations of pollen and nectar by fipronil (Chauzat et al., 2006; Mullin et al., 2010; Bonmatin et al., 2015).

B. thuringiensis is a gram-positive soil bacterium known since the early 1900s for its insecticidal properties, mainly against lepidopterans. Once ingested and activated in the intestinal tract of the target insect, the crystal toxins (Cry toxins) produced by the bacterium cause cell lysis and ultimately lead to insect death (Gill et al., 1992; Bravo et al., 2007; Vachon et al., 2012). Formulations 
with Bt spores are widely used in crop protection where Bt serovar kurstaki (Btk) is the most used strain. Adult honey bees could therefore be exposed to Bt by foraging in an area treated with Btbased products, while the exposure by ingestion of pollen from genetically modified plants expressing Cry toxins may occur in both adult bees and brood. When the effects of Bt spores on bees were analyzed, Btk was not found to induce mortality in honey bees or bumblebees (Malone et al., 1999; Mommaerts et al., 2010). However, several studies have demonstrated that Cry toxins may induce adverse effects such as impairment of memory and learning capacities, or anti-feedant and repellent effects (Ramirez-Romero et al., 2005', 2008; Han et al., 2010).

In the agricultural environment, honey bees may come in contact with different phytopharmaceutical substances along with Bt-derived pesticides and combined exposures may occur. Indeed, it has been shown that the efficacy of Bt-based products on target insects can be synergized by an associated or a surrounding treatment with a chemical insecticide (Wu et al., 2001; MoralesRodriguez and Peck, 2009). However, no study has been conducted to assess the effects of combinations of Bt-based products and chemical insecticides on non-target insects (Duan et al., 2008). Here, attention was focused on a widely used phenylpyrazole systemic insecticide, fipronil, to which honey bees can be chronically exposed due to the frequent contamination of pollen sources (Chauzat et al., 2006; Mullin et al., 2010; Bernal et al., 2010). The exposure to these low concentrations of fipronil can cause relevant perturbations of the olfactive learning capacity and orientation of honey bees (El Hassani et al., 2005; Decourtye et al., 2009). Furthermore, fipronil has been considered because, besides its neural action on the insect GABA and $\mathrm{GluCl}$ receptors (Ikeda et al., 2003; Narahashi et al., 2010), it can also act in the intestinal tract as Bt toxins do (Vidau et al., 2009; da Silva Cruz et al., 2010) and can enhance the impact of a honey bee gut pathogen, Nosema ceranae (Vidau et al., 2011; Aufauvre et al., 2012).

The importance of evaluating the responses of enzymes involved in detoxication of xenobiotics along with other toxicity endpoints has been evidenced for beneficial insects and honey bees (Desneux et al., 2007). In particular, the study of enzymatic modulation induced by pesticides in honey bees is increasingly investigated, revealing specific patterns of response (Badiou-Bénétau et al., 2012; Carvalho et al., 2013). However, this approach has not been applied to combinations of pesticides yet.

The objectives of the present study were therefore (i) to evaluate the effects of combined exposures to Bt spores and fipronil on honey bee survival and feeding behavior and (ii) to study physiological changes induced by the various treatments. In order to distinguish the effects of Bt spore components and Cry toxins, we used two different strains, Btk which expresses 6 Cry toxins and the Bt Cry ${ }^{-}$strain, which does not express any Cry toxin.

The mortality and the feeding behavior of the exposed bees were used as primary toxicity endpoints while at sublethal level, the modulation of the metabolism was assessed by investigating the activity of four enzymes: glutathione-S-transferase (GST), alkaline phosphatase (ALP), glucose-6-phosphate dehydrogenase (G6PD) and glyceraldehyde-3-phosphate dehydrogenase (GAPD). GST plays major roles in detoxication and in antioxidant defenses through the conjugation of glutathione to xenobiotics or endproducts of lipid peroxidation (Leaver and George, 1998; Sheehan et al., 2001). ALPs are involved in the hydrolysis of phosphomonoesters in digestive processes, cell signaling, adsorption and transport of molecules through the intestinal epithelium, and immune response in vertebrates and insects (Chen et al., 2011; Coleman, 1992; Vlahovic et al., 2009; Aufauvre et al., 2012). In honey bees, GST and ALP are important bioindicators to evaluate metabolic modulations induced by heavy metals (Bounias et al., 1996), pesticides (Badiou-Bénéteau et al., 2012, 2013, Carvalho et al., 2013) and pathogens (Dussaubat et al., 2012). GAPD and G6PD are involved in the glycolysis pathway and in the pentose phosphate pathway, respectively. Several studies highlighted that GAPD can be subjected to variations in concentration that are involved in transcriptional gene regulation, induction of apoptosis (Sirover, 2005; Ortiz-Ortiz et al., 2010) and response to oxidative stress (Nicholls et al., 2012). Therefore, GAPD can be considered a metabolic sensor of oxidative conditions. The inhibition of GAPD results in increase of G6PD activity, which is directly involved in oxidative stress remediation (Grant, 2008). Consequently, GAPD and G6PD can be used as complementary indicators of oxidative stress eventually caused by exposure to pesticides.

\section{Materials and methods}

\subsection{Tested products and reagents}

The 4Q7 Bt Cry $^{-}$(Bt Cry $^{-}$) and 4D1 Bt kurstaki (Btk) strains were obtained from the Bacillus Genetic Stock Center at Ohio State University. Bt $\mathrm{Cry}^{-}$is a modified strain that has been cured of the plasmid harboring the Cry genes (Gonzàlez et al., 1982), and Btk is the kurstaki strain that expresses the Cry1Aa, Cry1Ab, Cry1Ac, Cry2Aa, Cry2Ab and Cry2Ac toxins (Dulmage, 1970). Fipronil pure active ingredient was obtained from Cluzeau Info Labo (France). Beeboost ${ }^{\circledR}$ was obtained from Apimiel 81 (Willer-sur-Thur, France). Glucose-6-phosphate, 3-phosphoglyceraldehyde, NADP ${ }^{+}$, $\mathrm{NADH}$, glutathione, 1-chloro-2,4-dinitrobenzene, L-cystein, 3-phosphoglycerate kinase, triethanolamine, trishydroxymethylaminomethane (Tris), Triton X-100, antipain, leupeptin, pepstatin $\mathrm{A}$, aprotinin, soybean trypsin inhibitor, $\mathrm{MgCl}_{2}, \mathrm{NaCl}$, ethylenediaminetetraacetic acid (EDTA), NaKHPO, $\mathrm{NaH}_{2} \mathrm{PO}_{4}$ and p-nitrophenol were purchased from Sigma-Aldrich (Saint QuentinFallavier, France).

\subsection{Honey bees}

Apis mellifera mellifera honey bees were taken from 4 queenright colonies carefully monitored to check their health status. Emerging bees were obtained by placing brood frames in an incubator at controlled conditions $\left(34{ }^{\circ} \mathrm{C} \pm 2{ }^{\circ} \mathrm{C} ; 60 \% \pm 10 \%\right.$ relative humidity; darkness) for one day. Newly emerged bees from the 4 colonies were mixed and randomly placed into plastic cages $(6 \times 8.5 \times 10 \mathrm{~cm})$, without anesthesia, in groups of 40 individuals per cage, with a source of queen pheromone blend (one third of commercial Beeboost stick). The cages were then placed in an incubator at controlled conditions $\left(34{ }^{\circ} \mathrm{C} \pm 2{ }^{\circ} \mathrm{C} ; 60 \% \pm 10 \%\right.$ relative humidity; darkness) until the end of the experiment (Williams et al., 2013). After one day of adaptation to experimental conditions, dead honey bees were removed and replaced with other bees of the same age kept aside for this purpose, and the cages were randomly assigned to the different treatment groups. Fresh multi-floral pollen, checked for its toxicological quality by multiresidue analysis (86 of the most used pesticides) (Wiest et al., 2011) was provided for the first 3 days and then replaced with a commercial protein preparation (Provita'bee ${ }^{\circledR}$ ) added to the feeding syrup at the concentration of $1 \%(\mathrm{v} / \mathrm{v})$.

\subsection{Modalities of treatment}

Honey bees were exposed to the treatments $10 \mathrm{~h}$ per day, by feeding with $50 \%(\mathrm{w} / \mathrm{v}$ ) sucrose syrup containing the pesticides at the appropriate concentrations. During the remaining $14 \mathrm{~h}$, bees were provided with candy and water ad libitum. Bees were exposed to the contaminated solutions for 10 days, which is consistent with the period during which nurse bees consume both 
Version définitive du manuscrit publiée dans / Final version of the manuscript published in :

Ecotoxicology and Environmental Safety (2016), Vol. 127, p. 205-213, DOI: 10.1.016/j.ecoenv.2016.01.028

Journal homepage: www.elsevier.com/locatelecoenv

nectar and pollen (Rortais et al., 2005). Syrup consumption was recorded daily for the 10 days of exposure to pesticides and related to the daily number of surviving bees. Mortality was recorded every day until the end of the trial (25 days). The spore solutions of Bt strains (Bt Cry ${ }^{-}$and Btk) were tested at two concentrations, 100 and $1000 \mu \mathrm{g} / \mathrm{L}$, corresponding to $1.4 \times 10^{3}$ and $1.4 \times 10^{4} \mathrm{CFU} / \mathrm{mL}$, respectively. These concentrations are 8357 and 836 -fold lower than the common application rate for Bt kurstaki commercial formulations $\left(1.17 \times 10^{10} \mathrm{CFU} / \mathrm{g} ; 33.2 \mathrm{~g} / \mathrm{L}\right)$, respectively (European Food Safety Authority (EFSA), 2012). Fipronil was tested at the concentration of $1 \mu \mathrm{g} / \mathrm{L}(d=1.149 ; 0.87 \mu \mathrm{g} / \mathrm{kg}$ fipronil), which is consistent with the residual contamination of fresh and stored pollen (Chauzat et al., 2006; Bernal et al., 2010; Mullin et al., 2010; Pareja et al., 2011). Stock solutions of Bt and fipronil were prepared in water and DMSO respectively and stored at $-20^{\circ} \mathrm{C}$. All feeding sucrose solutions contained a final concentration of $0.1 \%$ DMSO $(\mathrm{v} / \mathrm{v})$ and were freshly prepared daily. To investigate the effects of fipronil-Bt combinations, 10 treatment groups were set up, corresponding to control bees that received only uncontaminated sucrose solution containing $0.1 \%$ DMSO, bees exposed to fipronil alone, Bt $\mathrm{Cry}^{-}$or Btk strain alone (two concentrations for each strain) and bees exposed to the combinations of Bt spores and fipronil. For each treatment group, 6 replicates were done (40 honey bees per replicate). Fipronil concentration was checked by GC-MS/MS (Wiest et al., 2011) and the relative standard deviation was less than $5.9 \%$.

\subsection{Enzyme assays}

To prevent any animal suffering, all tissues used for enzyme assays were removed from anaesthetized then decapitated bees. In surviving bees, head, midgut and abdomen devoid of the intestine were sampled, weighed and stored at a $-80^{\circ} \mathrm{C}$ until analysis. Tissues were homogenized at $4{ }^{\circ} \mathrm{C}$ in an extraction medium with a Qiagen ${ }^{\circledR}$ Tissue Lyser II $(30 \mathrm{~Hz}$, three periods of $30 \mathrm{~s}$, at 30 -s intervals) to make a $10 \%(\mathrm{w} / \mathrm{v})$ extract. The extraction medium consisted of $10 \mathrm{mM} \mathrm{NaCl}, 1 \%(\mathrm{w} / \mathrm{v}$ ) Triton X-100 and $40 \mathrm{mM}$ sodium phosphate $\mathrm{pH} 7.4$, and contained $2 \mu \mathrm{g} / \mathrm{ml}$ antipain, leupeptin and pepstatin A, 25 units $/ \mathrm{ml}$ aprotinin and $0.1 \mathrm{mg} / \mathrm{ml}$ soybean trypsin inhibitor as protease inhibitors (Belzunces et al., 1990). Tissue extracts were centrifuged at $4{ }^{\circ} \mathrm{C}$ for $20 \mathrm{~min}$ at $1,5000 \mathrm{~g}$ and the resulting supernatants were subjected to analysis. For each treatment group, 4 extracts of 5 tissues each were achieved and assayed in triplicate.

Glutathione-S-Transferase (GST) was spectrophotometrically assayed at $340 \mathrm{~nm}$, in a reaction medium containing $2.5 \mathrm{mM}$ reduced glutathione, $1 \mathrm{mM}$ 1-chloro-2,4-dinitrobenzene, $1 \mathrm{mM}$ EDTA and $100 \mathrm{mM} \mathrm{Na/K-phosphate} \mathrm{at} \mathrm{pH} \mathrm{7.4,} \mathrm{using} \mathrm{a} \mathrm{method}$ adapted from Habig et al. (1974). Alkaline phosphatase (ALP) activity was assayed at $410 \mathrm{~nm}$ in a reaction medium containing $20 \mathrm{mM} \mathrm{MgCl}$, $2 \mathrm{mM}$ p-nitrophenyl phosphate and $100 \mathrm{mM}$ Tris$\mathrm{HCl}$ pH 8.5 (Bounias et al., 1996). Glucose-6-phosphate dehydrogenase (G6PD) activity was assayed at $340 \mathrm{~nm}$ in a reaction medium containing $1 \mathrm{mM}$ disodium D-Glucose 6-phosphate, $0.5 \mathrm{mM} \mathrm{NADP}^{+}, 10 \mathrm{mM} \mathrm{MgCl}$ and $100 \mathrm{mM}$ Tris-HCl pH 7.4. Glyceraldeyde-3-phosphate dehydrogenase (GAPD) activity was assessed at $340 \mathrm{~nm}$ in a reaction medium containing $7 \mathrm{mM}$ 3-phosphoglyceraldehyde, $4 \mathrm{mM}$ L-cysteine, $2 \mathrm{mM} \mathrm{MgSO}_{4}, 120 \mu \mathrm{M}$ $\mathrm{NADH}, 1.2 \mathrm{mM}$ ATP, $1 \mathrm{mM}$ EDTA, 5 units/ml 3-phosphoglycerate kinase and $80 \mathrm{mM}$ triethanolamine at $\mathrm{pH}$ 7.6.

\subsection{Statistical analysis}

Daily mortality data were organized in a survival table and analyzed through a Cox proportional hazard regression model. Syrup consumption data were processed through a repeated-
Table 1

Statistical significances of physiological modulations. Results of two-way ANOVA performed on enzymatic activities considering the treatments with Fipronil (treated, untreated) and Bt (Bt $\mathrm{Cry}^{-}$, Btk, untreated) as factors. The analysis was separately carried out for bees sampled on day 10 and day 20. Differences were considered significant for $p<0.05$.

\begin{tabular}{|c|c|c|c|c|c|}
\hline Enzyme & Sampling day & Factor & D.f. & $F$ & $p$ \\
\hline \multirow[t]{6}{*}{ GST (head) } & \multirow[t]{3}{*}{10} & Fipronil & 1,114 & 5.402 & 0.022 \\
\hline & & $\mathrm{Bt}$ & 2,114 & 94.428 & $<0.001$ \\
\hline & & Fip $\times$ Bt & 2,114 & 3.704 & 0.028 \\
\hline & \multirow[t]{3}{*}{20} & Fipronil & 1,114 & 15.141 & $<\mathbf{0 . 0 0 1}$ \\
\hline & & $\mathrm{Bt}$ & 2,114 & 55.628 & $<0.001$ \\
\hline & & Fip $\times$ Bt & 2,114 & 1.072 & 0.345 \\
\hline \multirow[t]{6}{*}{ GST (midgut) } & \multirow[t]{3}{*}{10} & Fipronil & 1,114 & 1.312 & 0.254 \\
\hline & & $\mathrm{Bt}$ & 2,114 & 5.542 & 0.005 \\
\hline & & Fip $\times$ Bt & 2,114 & 2.591 & 0.08 \\
\hline & \multirow[t]{3}{*}{20} & Fipronil & 1,114 & 0.495 & 0.483 \\
\hline & & $\mathrm{Bt}$ & 2,114 & 131.656 & $<0.001$ \\
\hline & & Fip $\times$ Bt & 2,114 & 3.713 & 0.027 \\
\hline \multirow[t]{6}{*}{ ALP (midgut) } & \multirow[t]{3}{*}{10} & Fipronil & 1,110 & 27.591 & $<0.001$ \\
\hline & & $\mathrm{Bt}$ & 2,110 & 12.421 & $<0.001$ \\
\hline & & Fip $\times$ Bt & 2,110 & 0.393 & 0.676 \\
\hline & \multirow[t]{3}{*}{20} & Fipronil & 1,109 & 1.884 & 0.173 \\
\hline & & $\mathrm{Bt}$ & 2,109 & 30.453 & $<0.001$ \\
\hline & & Fip $\times$ Bt & 2,109 & 0.56 & 0.573 \\
\hline \multirow[t]{6}{*}{ GAPD (abdomen) } & \multirow[t]{3}{*}{10} & Fipronil & 1,113 & 4.110 & 0.045 \\
\hline & & $\mathrm{Bt}$ & 2,113 & 13.076 & $<0.001$ \\
\hline & & Fip $\times$ Bt & 2,113 & 0.971 & 0.382 \\
\hline & \multirow[t]{3}{*}{20} & Fipronil & 1,114 & 25.853 & $<0.001$ \\
\hline & & $\mathrm{Bt}$ & 2,114 & 2.112 & 0.126 \\
\hline & & Fip $\times$ Bt & 2,114 & 0.404 & 0.668 \\
\hline \multirow{6}{*}{ G6PD (abdomen) } & \multirow[t]{3}{*}{10} & Fipronil & 1,107 & 0.407 & 0.525 \\
\hline & & $\mathrm{Bt}$ & 2,107 & 3.443 & 0.035 \\
\hline & & Fip $\times$ Bt & 2,107 & 0.427 & 0.653 \\
\hline & \multirow{3}{*}{20} & Fipronil & 1,114 & 8.605 & 0.004 \\
\hline & & $\mathrm{Bt}$ & 2,114 & 1.831 & 0.165 \\
\hline & & Fip $\times$ Bt & 2,107 & 6.199 & 0.003 \\
\hline
\end{tabular}

measures ANOVA followed by Bonferroni post-hoc analysis, in order to perform comparisons between groups. The effects of the treatments with Bt and fipronil on GST, ALP, GAPD and G6PD activities were evaluated with a two-way ANOVA. Tukey HSD posthoc test was then performed for comparisons between the different treatment groups. For the enzymatic activities, post-hoc results are shown in the box plots, while ANOVA results are integrated in Table 1. All analyses were performed with $\mathrm{R}$ software (version 3.0.2).

\section{Results}

\subsection{Chronic toxicity of Bt spores and fipronil, alone or in combination}

Bees were exposed for 10 days to Bt spores at 100 and $1000 \mu \mathrm{g} /$ $\mathrm{L}$ and fipronil at $1 \mu \mathrm{g} / \mathrm{L}$, alone or in combination, and mortality was recorded for a total period of 25 days. The survival rate was higher than $95 \%$ until the end of the treatment period (day 10) and remained above $85 \%$ until the 25th day of observation, for all the treatment groups (Fig. 1A and B). Overall, bees treated with Bt $\mathrm{Cry}^{-}$had a slightly lower survival rate as compared with control bees and Btk-treated bees (Cox model, $p<0.05$ ). The combination with fipronil did not elicit any significant effect on bee survival (Cox model, $p>0.05$ ).

\subsection{Effects of Bt spores and fipronil on the feeding behavior}

The influence of the different treatments on the feeding behavior of honey bees was investigated by measuring the daily intake of feeding syrup during the $10-\mathrm{h}$ exposure period. The 
Version définitive du manuscrit publiée dans / Final version of the manuscript published in :

Ecotoxicology and Environmenta! Safety (2016), Vol. 127, p. 205-213, DOI: 10.1016/i..ecoenv.2016.01.028

Journal homepage: www.elsevier.com/locatelecoenv
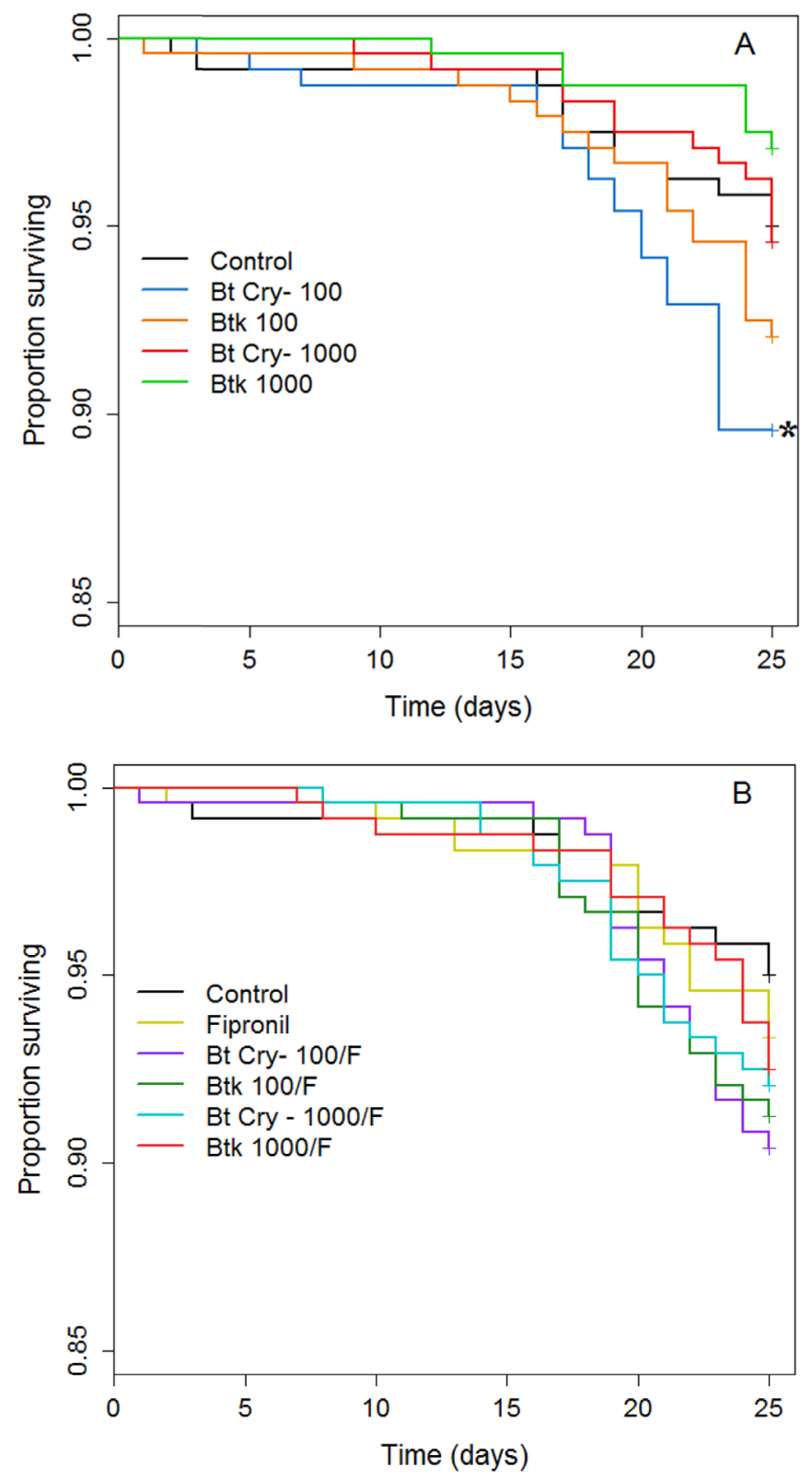

Fig. 1. Effect of Bt spores and fipronil on survival of newly emerged bees. After emergence, bees were orally exposed for 10 days to spores from Bt Cry ${ }^{-}$and Btk strains at 0 (control), 100 and $1000 \mu \mathrm{g} / \mathrm{L}$ in the sucrose feeding solution, alone (A) or in combination with fipronil at $1 \mu \mathrm{g} / \mathrm{L}$ (B). The mortality was recorded over 25 days. Data represent the proportions of surviving individuals over time; each curve represents 6 repetitions. Asterisk represents $p<0.05$.

analysis of overall data showed that the syrup consumption significantly increased with time (ANOVA, $F_{(9,450)}=56.167$, $p=1.10^{-16}$ ), but was influenced neither by the Bt treatment (ANOVA, $\quad F_{(2,57)}=1.641, \quad p=0.203$ ) nor by fipronil (ANOVA, $\left.F_{(1,58)}=3.675, p=0.060\right)$.

\subsection{Physiological modulations induced by Bt spores and fipronil}

Since no apparent toxicity was observed after the exposure of emerging bees to Bt spores and fipronil, alone or in combination, we wanted to see whether physiological changes could occur in the absence of mortality. Physiological changes were studied by investigating the activity of enzymes involved in the intermediary and detoxication metabolisms. Activities of glutathione-S-transferase (GST), alkaline phosphatase (ALP), glucose-6-phosphate dehydrogenase (G6PD) and glyceraldehyde-3-phosphate dehydrogenase (GAPD) were measured at the end of the chronic exposure (day 10) and 10 days after (day 20).

\subsection{GST modulation}

GST tissue activity was measured in heads and midguts. In the heads, GST activity was significantly modulated by the exposure to Bt spores (Table 1 and Fig. 2). In particular, Btk-treated bees exhibited a significantly lower GST activity compared with control and $\mathrm{Bt} \mathrm{Cry}^{-}$at both sampling dates (Tukey HSD, $p<0.001$ for all comparisons). A GST activity similar to that of controls was generally observed in bees exposed to Bt Cry ${ }^{-}$(Tukey HSD, $p<0.05$ ), except at $100 \mu \mathrm{g} / \mathrm{L}$ at day 10 and at $1000 \mu \mathrm{g} / \mathrm{L}$ at day 20, for which the activities were respectively higher and lower than those of controls (Tukey HSD, $p<0.05$ for both comparisons). Fipronil alone did not induce significant changes in GST at day 10 and 20 (Tukey HSD, $p>0.05$ for both comparisons). However, ANOVA performed on all data showed that fipronil significantly modulated the overall response, at both sampling dates (Table 1). In particular, at day 10, the interaction between fipronil and Bt was significant (Table 1) and fipronil abolished the increase of GST activity induced by Bt $\mathrm{Cry}^{-}$spores at $100 \mu \mathrm{g} / \mathrm{L}$ (Tukey HSD, $p<0.001$ ) (Fig. 2). At day 20, fipronil had an opposite effect by abolishing the decrease of GST activity induced by Bt $\mathrm{Cry}^{-}$spores at $1000 \mu \mathrm{g} / \mathrm{L}$ (Tukey HSD, $p<0.001$ ) (Fig. 2).

In the midgut, GST overall activity was significantly modified by Bt spores (Table 1 and Fig. 2) and post-hoc analyses evidenced different trends between sampling dates. Comparing the overall response to Bt strains at day 10, bees treated with $\mathrm{Bt} \mathrm{Cry}^{-} \mathrm{ex}^{-}$ hibited a GST activity similar to that of controls (Tukey HSD, $p>0.05$ ), while bees treated with Btk exhibited an activity higher than those of controls and bees treated with Bt Cry ${ }^{-}$(Tukey HSD, $p<0.05$ for both comparisons). More specifically, the comparison between all treatment groups showed that the bees exposed to Btk at $1000 \mu \mathrm{g} / \mathrm{L}$, combined or not with fipronil, exhibited the highest activity (Fig. 2). Conversely, at day 20, Bt spores induced a decrease of midgut GST, which was more pronounced for Btk spores than for $\mathrm{Bt} \mathrm{Cry}^{-}$spores (Tukey HSD, $p<0.05$ for all comparisons) (Fig. 2). Fipronil alone did not induce a significant variation of GST at either sampling date (Tukey HSD, $p>0.05$, for both comparisons). The analysis of the overall data with ANOVA did not highlight an influence of fipronil on midgut GST activity at day 10, even though a significant interaction between fipronil and Bt was evidenced at day 20 (Table 1 and Fig. 2).

In summary, GST activity was significantly modulated by Btk that induced a specific decrease of enzymatic activity, particularly in the head. Fipronil modulated GST activity and interacted with Bt in head and midgut, even though at different times.

\subsection{ALP modulation}

The ALP activity measured in the midguts (Fig. 3) was significantly modulated by Bt spores at days 10 and 20 (Table 1). At day 10, Bt spores induced an increase of ALP activity (Table 1), which was more pronounced for Btk spores than for Bt $\mathrm{Cry}^{-}$ spores (Tukey HSD, $p<0.05$ ) (Fig. 3). Conversely, at day 20, Bt spores elicited a decrease of ALP activity (Table 1), with no significant differences between Bt $\mathrm{Cry}^{-}$and Btk strains (Tukey HSD, $p>0.05$ ) (Fig. 3). Fipronil alone did not elicit a significant variation of ALP activity at either sampling date (Tukey HSD, $p>0.05$ ) (Fig. 3). However, at day 10, ANOVA evidenced that fipronil elicited a significant increase of ALP activity (Table 1, Fig. 3). In particular, the post-hoc analysis highlighted a significant positive modulation for Bt Cry ${ }^{-}$at $100 \mu \mathrm{g} / \mathrm{L}$ (Tukey HSD, $p<0.001$ ) and Btk at $100 \mu \mathrm{g} / \mathrm{L}$ (Tukey HSD, $p<0.05$ ) (Fig. 3). Conversely, fipronil did not have a 


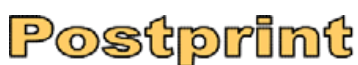

Version définitive du manuscrit publiée dans / Final version of the manuscript published in :

Ecotoxicology and Environmental Safety (2016), Vol. 127, p. 205-213, DOI: 1.0.1.016/j.ecoenv.2016.01.028

Journal homepage: www.elsevier.com/locatelecoenv
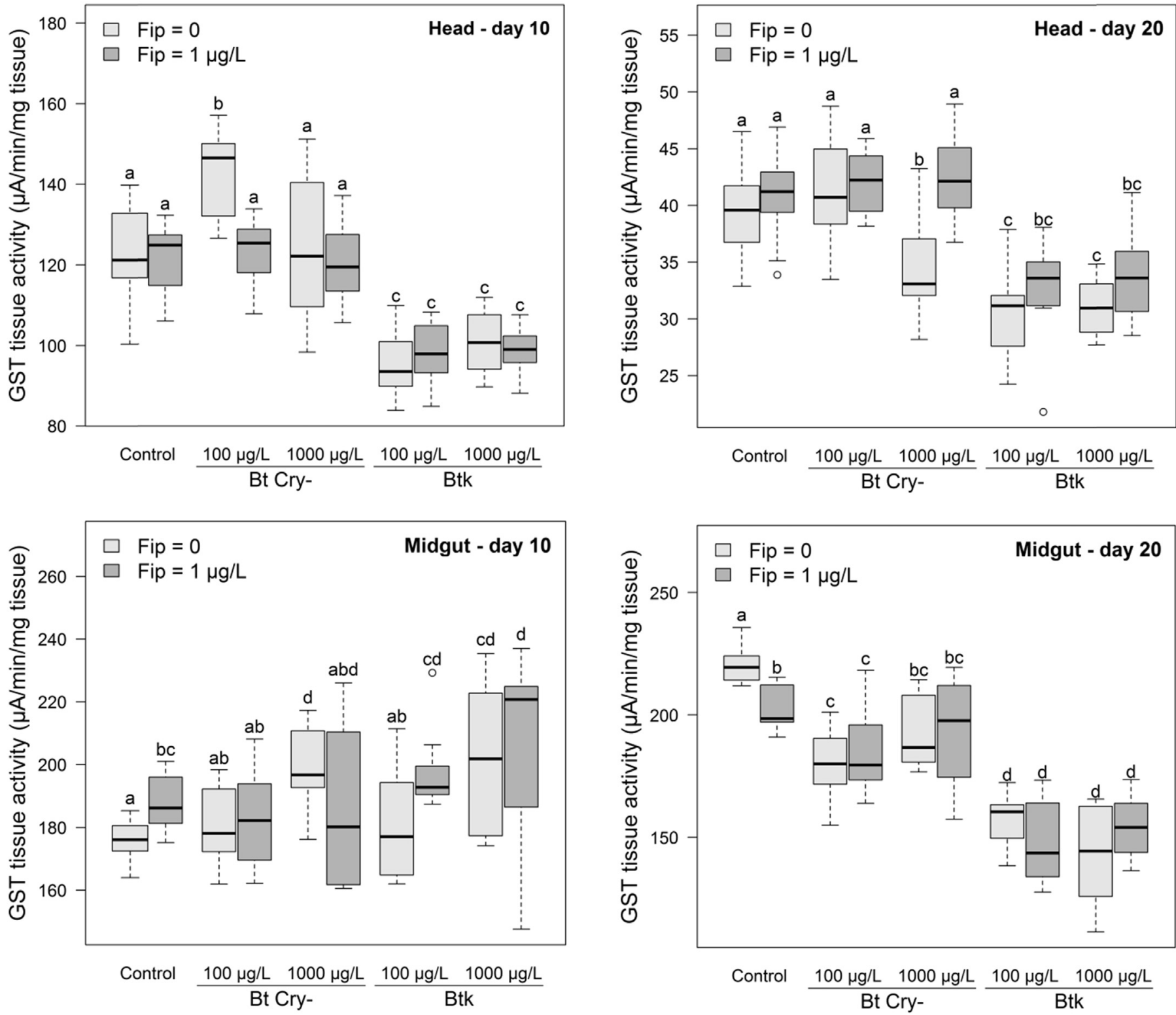

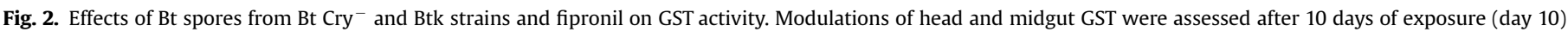

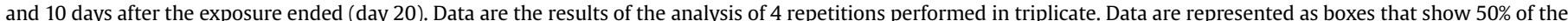

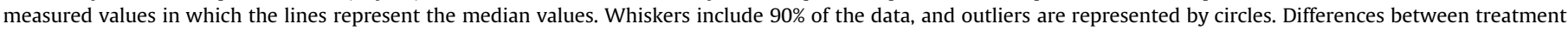
groups were estimated through Tukey HSD post-hoc comparisons. Data with different letters are significantly different $(p<0.05)$.

significant effect on overall ALP activity at day 20 (Table 1), except for the combination with Btk at $1000 \mu \mathrm{g} / \mathrm{L}$ for which a significant decrease of ALP activity could be observed (Tukey HSD, $p<0.05$ ) (Fig. 3).

In summary, ALP activity increased in response to Bt at day 10 , with a specific effect due to Btk, but decreased at day 20. Fipronil induced a higher activity at day 10 , which was not observed ten days later.

\subsection{GAPD modulation}

GAPD activity was measured in the abdomens devoid of gut and honey sac (Fig. 4). At day 10, Bt treatment had a significant effect (Table 1). The post-hoc analysis showed that Bt Cry ${ }^{-}$and Btk spores significantly increased GAPD activity (Tukey HSD, $p<0.001$ for both comparisons). Overall, Bt Cry ${ }^{-}$and Btk strains induced similar responses (Tukey HSD, $p>0.05$ ), even though bees treated with Bt Cry $100 \mu \mathrm{g} / \mathrm{L}^{-}$and Bt Cry ${ }^{-} 1000 \mu \mathrm{g} / \mathrm{L}$ displayed a different
GAPD activity compared with bees treated with Btk $100 \mu \mathrm{g} / \mathrm{L}$ and Btk $1000 \mu \mathrm{g} / \mathrm{L}$, respectively (Tukey HSD, $p<0.05$ ) (Fig. 4). At day 20 , Bt spores did not induce a significant effect on GAPD activity (Table 1) (Fig. 4). Fipronil alone induced an increase of GAPD activity at both sampling dates, even though this effect was significant only at day 20 (Tukey HSD, $p<0.05$ ) (Fig. 4). However, considering the overall data, fipronil was able to modulate the activity of GAPD, with a general increase observed both at day 10 and 20 (Table 1). This effect was particularly significant for Btk $100 \mu \mathrm{g} / \mathrm{L}$ at day 10 (Tukey HSD, $p<0.01$ ) and for Btk $1000 \mu \mathrm{g} / \mathrm{L}$ at day 20 (Tukey HSD, $p<0.001$ ) (Fig. 4).

In summary, GAPD was modulated by Bt at day 10 but not at day 20, without a specific effect of Btk. Fipronil induced a significant increase in enzymatic activity at both days.

\subsection{G6PD modulation}

G6PD activity was measured in the abdomens devoid of gut 


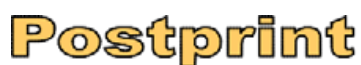

Version définitive du manuscrit publiée dans / Final version of the manuscript published in :

Ecotoxicology and Environmenta! Safety (2016), Vol. 127, p. 205-213, DOI: 10.1.016/i.ecoenv.2016.01.028

Journal homepage: www.elsevier.com/locate/ecoenv

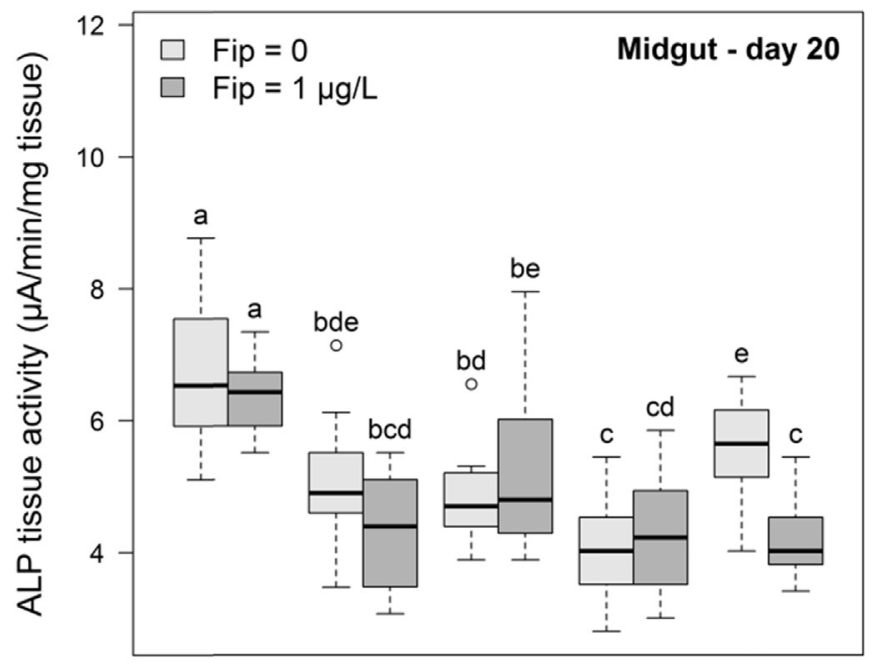

Control $\frac{100 \mu \mathrm{g} / \mathrm{L} \quad 1000 \mu \mathrm{g} / \mathrm{L}}{\text { Bt Cry- }} \frac{100 \mu \mathrm{g} / \mathrm{L} \quad 1000 \mu \mathrm{g} / \mathrm{L}}{\text { Btk }}$
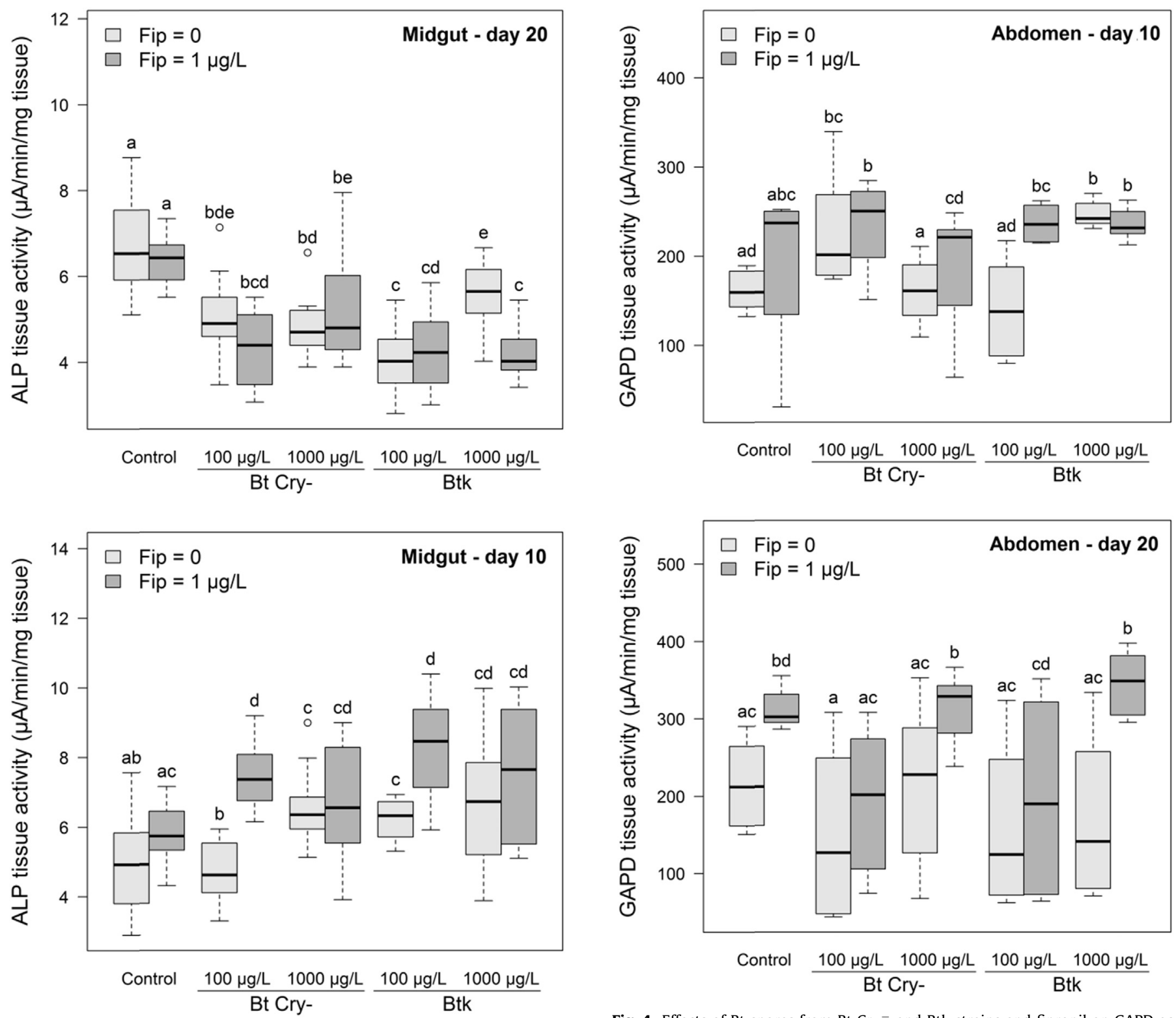

Fig. 3. Effects of Bt spores from Bt $\mathrm{Cry}^{-}$and Btk strains and fipronil on ALP activity. Modulations of ALP were assessed in midguts after 10 days of exposure (day 10) and 10 days after the exposure ended (day 20). Data are the results of the analysis of 4 repetitions performed in triplicate. Data are represented as boxes including $50 \%$ of the measured values in which the lines represent the median values. Whiskers include $90 \%$ of the data, and outliers are represented by circles. Differences between treatment groups were estimated through Tukey HSD post-hoc comparisons. Data with different letters are significantly different $(p<0.05)$.

and honey sac (Fig. 5). Overall, Bt spores induced significant changes in G6PD activity at day 10 (Table 1), particularly for Bt $\mathrm{Cry}^{-} 100 \mu \mathrm{g} / \mathrm{L}$ that induced a significant higher activity compared with controls (Tukey HSD, $p<0.05$ ) (Fig. 5). Conversely, at day 20 Bt induced no significant modifications of G6PD activity (Table 1). Bees treated with $\mathrm{Bt} \mathrm{Cry}^{-}$exhibited a different response when compared with bees treated with Btk at day 10 (Tukey HSD, $p<0.05$ ), while they exhibited similar levels of G6PD activity at day 20 (Tukey HSD, $p>0.05$ ) (Fig. 5). Fipronil alone induced a significant increase in G6PD activity only at day 20 (Tukey HSD, $p<0.05$ ) (Fig. 5). Overall, fipronil elicited a modulation of G6PD activity at day 20 , with a significant interaction with Bt (Table 1 and Fig. 5). This effect was not observed at day 10 (Table 1 and Fig. 5) even though it counteracted the effect of Btk spores at

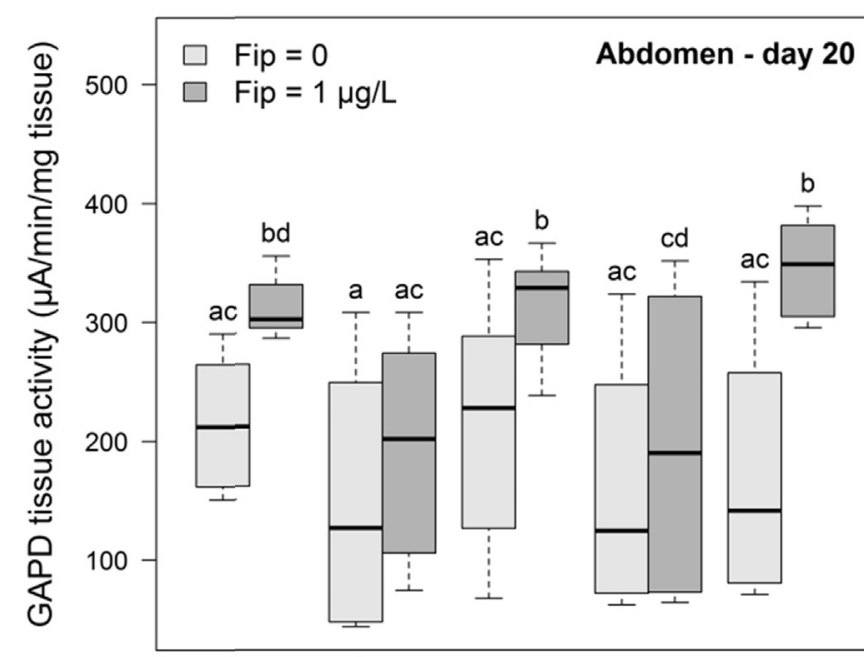

Control $\frac{100 \mu \mathrm{g} / \mathrm{L} 1000 \mu \mathrm{g} / \mathrm{L}}{\text { Bt Cry- }} \frac{100 \mu \mathrm{g} / \mathrm{L} \quad 1000 \mu \mathrm{g} / \mathrm{L}}{\text { Btk }}$

Fig. 4. Effects of Bt spores from Bt $\mathrm{Cry}^{-}$and Btk strains and fipronil on GAPD activity. Modulations of GAPD were assessed in abdomens after 10 days of exposure (day 10) and 10 days after the exposure ended (day 20). Data are the results of the analysis of 4 repetitions performed in triplicate. Data are represented as boxes including $50 \%$ of the measured values in which the lines represent the median values. Whiskers include $90 \%$ of the data, and outliers are represented by circles. Differences between treatment groups were estimated through Tukey HSD post-hoc comparisons. Data with different letters are significantly different $(p<0.05)$.

$100 \mu \mathrm{g} / \mathrm{L}$ and induced a decrease of G6PD activity when combined with Btk spores at $1000 \mu \mathrm{g} / \mathrm{L}$ (Tukey HSD, $p<0.05$ for both comparisons).

In summary, the activity of G6PD was significantly modulated by $\mathrm{Bt}$ only at day 10 and by fipronil, alone or combined with $\mathrm{Bt}$, at day 20.

\section{Discussion}

\subsection{Toxicity of Bt spores alone or in combination with fipronil}

The toxicity of Bt spores has been investigated with a widely used Bt strain, Bt ser. kurstaki (Btk). The ingestion of non-pathogenic bacteria, which include bacterial coat components, may 


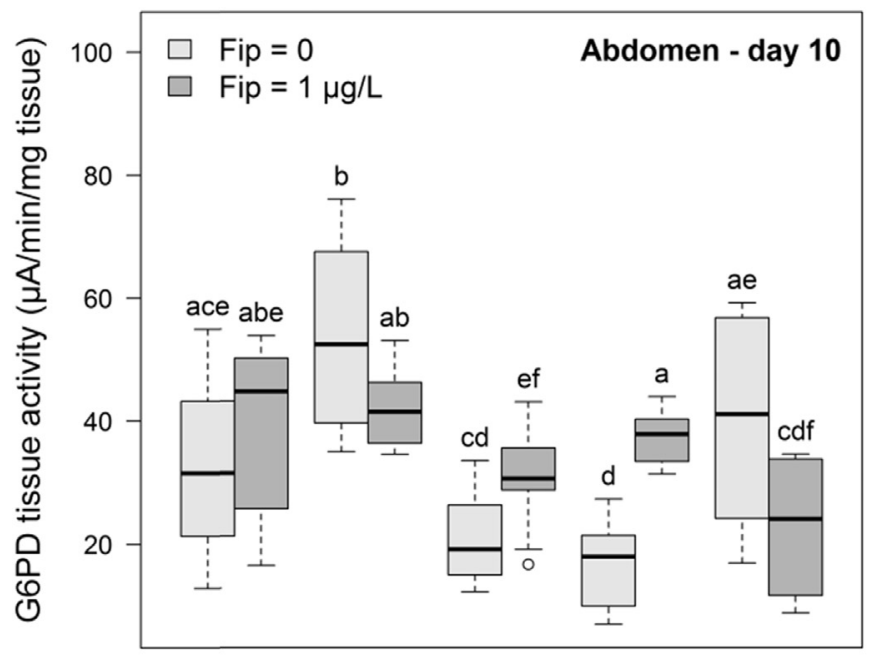

Control $100 \mu \mathrm{g} / \mathrm{L} \quad 1000 \mu \mathrm{g} / \mathrm{L} \quad 100 \mu \mathrm{g} / \mathrm{L} \quad 1000 \mu \mathrm{g} / \mathrm{L}$ Bt Cry- Btk

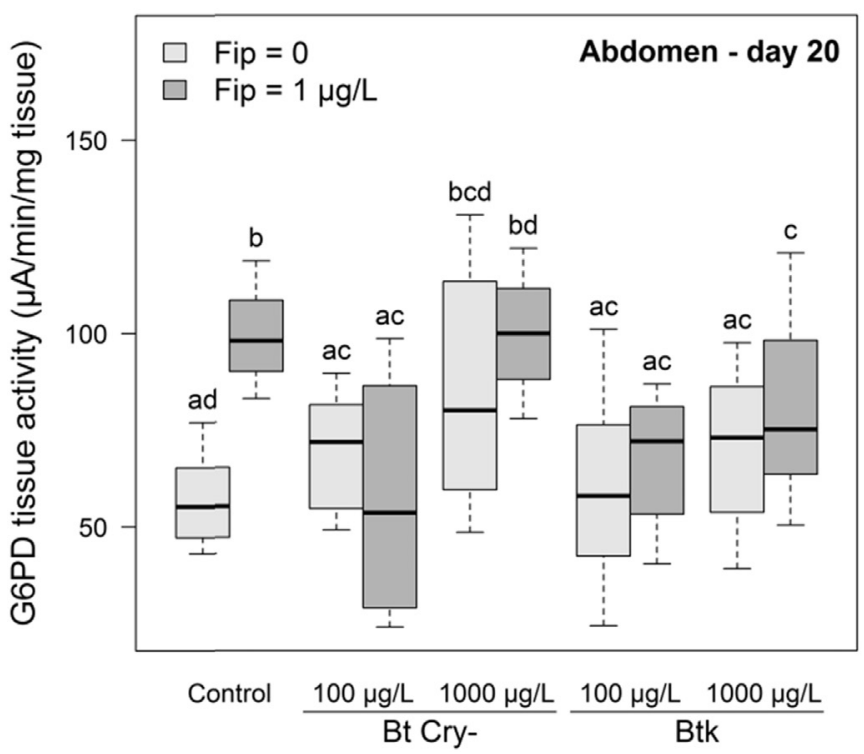

Fig. 5. Effects of Bt spores from Bt $\mathrm{Cry}^{-}$and Btk strains and fipronil on G6PD activity. Modulations of G6PD were assessed in abdomens after 10 days of exposure (day 10) and 10 days after the exposure ended (day 20). Data are the results of the analysis of 4 repetitions performed in triplicate. Data are represented as boxes including $50 \%$ of the measured values in which the lines represent the median values. Whiskers include $90 \%$ of the data, and outliers are represented by circles. Differences between treatment groups were estimated through Tukey HSD post-hoc comparisons. Data with different letters are significantly different $(p<0.05)$.

modulate honey bee physiology and particularly immunity (Evans and Lopez, 2004). Thus, a Bt strain without the Cry toxin-encoding genes (Bt $\mathrm{Cry}^{-}$) has been used as a reference to distinguish the effects elicited by the bacterial spore components from those elicited by Cry toxins. The statistical analysis of survival rates indicated a significant slightly higher mortality in bees treated with $\mathrm{Bt} \mathrm{Cry}^{-}$spores alone. However, no treatment elicited mortality higher than $12 \%$ at day 25 , a value that could be considered physiological. Thus, our results show that Bt spores of the kurstaki strain have no detrimental effect on the survival of bees exposed chronically and do not present a significant toxicity due to the encoded Cry toxins. The lack of toxicity of Bt products to young bees is in agreement with the results obtained by Malone et al. (1999) and Ramirez-Romero et al. (2008) for young adult bees.

Several studies have reported the enhanced toxicity of $B$. thuringiensis in combination with chemical insecticides in lepidopterans and coleopterans (Sudhakar and Dhingra, 2002; Singh et al., 2007; Morales-Rodriguez and Peck, 2009). Because Bt toxins primarily act in the digestive tract, the hypothesis of a combined toxicity has been tested with fipronil, a neurotoxic insecticide that can affect intestinal cells in honey bees and mammals (Vidau et al., 2009; da Silva Cruz et al., 2010). The results demonstrated that the combined exposure to Bt spores and fipronil does not induce mortality higher than those elicited by the two stressors alone, regardless of the expression of Cry toxins.

\subsection{Physiological effects of Bt strains and fipronil}

In this study, Bt spores did not elicit any significant lethal effect in emerging bees exposed for 10 days. Thus, physiological changes were investigated in 3 compartments (head, midgut and abdomen) to reveal any potential systemic action of Bt spores. The present results show that the honey bee may exhibit physiological responses either specific to $\mathrm{Bt} \mathrm{Cry}^{-}$or Btk spores, or common to Bt $\mathrm{Cry}^{-}$and Btk spores, thus showing an action of spore components only. In all cases, such responses reveal that Bt spores may exhibit systemic physiological actions despite the absence of a significant lethal effect. Furthermore, in some instances, the modulations of the studied enzymes corresponded to long-lasting physiological changes induced by Bt spores because physiological variations are still observed 10 days after the exposure ended (at day 20).

In this experiment, GST activity was specifically reduced by Btk, which suggests that Cry toxins have elicited this response. However, this effect was markedly observed in the head, whereas in midgut, where Cry toxins should express their toxic activity, GST activity is increased by Bt treatment. Therefore, despite its role in oxidative stress, the complex profile of GST modulation evidenced in this study does not support the triggering of a physiological response to protect bees against an oxidative action of Bt spores. The modulation rather appears as a direct effect of Bt spores on GST activity, regardless of physiological protection. Fipronil showed a relevant effect on head GST and was involved in balancing the variations induced by Bt spores, particularly for Bt Cry ${ }^{-}$in the head. Conversely, fipronil did not produce a significant effect in the midgut, which has also been observed by Carvalho et al. (2013). This suggests the interest of measuring GST in both compartments in order to reveal the possible effects induced by a pesticide. The difference between the effects observed in the two compartments is not surprising considering the fact that in situ pesticide metabolism can occur in non-detoxifying tissues (Suchail et al., 2004). Thus, depending on the role of the enzyme and the forms expressed in different tissues, the modulation by stressors may be different.

ALP activity was enhanced following 10 days of exposure to $\mathrm{Bt}$ spores, which was particularly relevant for Btk spores. ALP has been recently reported to be involved in the toxicity of $B$. thuringiensis by acting as a secondary intestinal receptor for some Cry toxins (Upadhyay and Singh, 2011). Thus, the increase in ALP levels could be related to the presence of Cry toxins in the bee midgut at day 10. Ten days after the exposure to Bt spores ended, no enhancing effect of Bt spores was detected. By contrast, a decrease in ALP activity was observed. Interestingly, other studies demonstrated a lower ALP activity in honey bees treated with the gut pathogen Nosema ceranae (Dussaubat et al., 2012; Di Pasquale et al., 2013). Fipronil induced a significant increase of ALP after 10 days of exposure. This effect contrasts with the results obtained by Carvalho et al. (2013) that show a decrease in ALP activity induced by fipronil after an acute exposure. The discrepancy between these results can be partially explained by differences in exposure levels and modes, and in the physiology of young bees and foragers. However, the increase of ALP activity following the treatment with 
chemical pesticides, such as thiamethoxam, has already been observed in other studies (Badiou-Bénétau et al., 2012). In our experiment, this effect was no longer observed at day 20 , suggesting that ALP exhibited a time-dependent response to fipronil. The combination of Bt with fipronil was not associated to a specific response. This suggests that the combined effect of the two stressors in midgut we have hypothesized does not apply to ALP.

The effects of Bt spores on GAPD and G6PD, two key enzymes in carbohydrate metabolism, appear more dependent on the intensity of exposure and the nature of the stressor than for the other metabolic enzymes. In this study, GAPD was influenced by Bt treatment at the end of the 10-day exposure period. In particular, Btk at the highest concentration induced an increase of the GAPD activity, which might be linked to Cry toxins expression. Fipronil significantly enhanced GAPD activity at days 10 and 20, thus showing a persistent effect. GAPD is mainly involved in the glycolysis pathway and GAPD variations can occur in response to oxidative stress (Nicholls et al., 2012). In the presence of reactive oxygen species (ROS), GAPD can be inhibited (Chuang et al., 2005). This inhibition results in the deviation of the glucose flux towards the pentose phosphate pathway for the production of the antioxidant/reducer NADPH. The enhancement of the pentose phosphate pathway can be revealed by the increase of G6PD activity. Thus, the increase of G6PD might be a sign of the cellular response to oxidative conditions (Kletzien et al., 1994; Verma et al., 2007). However, here Bt spores caused an increased activity of GAPD that contrasts with the decrease of G6PD, which is not consistent with the induction of oxidative stress. The effect of fipronil at low concentrations is confirmed by the significant increase of GAPD and G6PD. However, the increase of both enzymes does not enable explaining the modulation as a response to oxidative stress.

\section{Conclusions}

This study confirms the weak lethal effect of Bt-derived plant protection products on honey bee survival in laboratory conditions. Furthermore, Bt spores modulate the activity of important enzymes, which may induce physiological impairments that could only be revealed by infra-clinic investigations. It is noteworthy that some of these modulations are specifically related to the presence of Cry toxins. The co-exposure to a chemical stressor like fipronil does not trigger any additive response on survival, which might indicate that the use of Bt has low impact in the case of a combined exposure with at least fipronil. However, fipronil is able to modulate the physiological effects elicited by Bt spores, even when it does not have an apparent effect by itself. Such a result confirms that this pesticide could interact at low concentrations with other environmental stressors. Consistently, our data stress the importance of assessing the impacts of physiological changes induced by the exposure to a pesticide on the functional integrity of honey bees.

\section{Conflict of interest}

The authors declare that they have no conflict of interests.

\section{Acknowledgments}

This work was funded by the French National Institute for the Agricultural Research (INRA, Grant no. 406-2012). MTR's Ph.D. mobility grant was funded by Marco Polo funding programme (University of Bologna (Programma Marco Polo 2011 - I Tornata)).
We thank Cecilia Costa for her assistance in language revisions and Antonio Masetti for his support in revising the article.

\section{References}

Aufauvre, J., Biron, D.G., Vidau, C., Fontbonne, R., Roudel, M., Diogon, M., Vigues, B., Belzunces, L.P., Delbac, F., Blot, N., 2012. Parasite-insecticide interactions: a case study of Nosema ceranae and fipronil synergy on honeybee. Sci. Rep. 2, 326.

Badiou-Bénéteau, A., Carvalho, S.M., Brunet, J.-L., Carvalho, G.A., Buleté, A., Giroud B., Belzunces, L.P., 2012. Development of biomarkers of exposure to xenobiotics in the honey bee Apis mellifera: application to the systemic insecticide thiamethoxam. Ecotoxicol. Environ. Saf. 82, 22-31.

Badiou-Bénétau, A., Benneveau, A., Géret, F., Delatte, H., Becker, N., Brunet, J.-L. Reynaud, B., Belzunces, L.P., 2013. Honeybee biomarkers as promising tools to monitor environmental quality. Environ. Int. 60, 31-41.

Belzunces, L.P., Theveniau, M., Masson, P., Bounias, M., 1990. Membrane acetylcholinesterase from Apis mellifera head solubilized by phosphatidylinositolspecific phospholipase C interacts with an anti-CRD antibody. Comp. Biochem. Physiol. B 95, 609-612.

Bernal, J., Garrido Bailén, E., Del Nozal, M.J. González-Porto, A.V., Martín, H.R. Diego, J.C., Jiménez, J.J., Bernal, J.L., Higes, M., 2010. Overview of pesticide residues in stored pollen and their potential effect on bee colony (Apis mellifera) losses in Spain. J. Econ. Entomol. 103, 1964-1971.

Bonmatin, J.M., Giorio, C., Girolami, V., Kreutzweiser, D., Krupke, C.H., Liess, M., Long, E., Marzaro, M., Mitchell, E.A., Noome, D.A., Simon-Delso, N., Tapparo, A., 2015. Environmental fate and exposure; neonicotinoids and fipronil. Environ. Sci. Pollut. Res. 22, 35-67.

Bounias, M., Kruk, I., Nectoux, M., Popeskovic, D., 1996. Toxicology of cupric salts on honeybees. V. Gluconate and sulfate action on gut alkaline and acid phosphatases. Ecotoxicol. Environ. Saf. 35, 67-76.

Bravo, A., Gill, S.S., Soberòn, M., 2007. Mode of action of Bacillus thuringiensis Cry and Cyt toxins and their potential for insect control. Toxicon 49, 423-435.

Carvalho, S.M., Belzunces, L.P., Carvalho, G.A., Brunet, J.L., Badiou-Beneteau, A., 2013. Enzymatic biomarkers as tools to assess environmental quality: a case study of exposure of the honeybee Apis mellifera to insecticides. Environ. Toxicol. Chem. 32, 2117-2124.

Chauzat, M.P., Faucon, J.P., Martel, A.C., Lachaize, J., Cougoule, N., Aubert, M., 2006. A survey of pesticide residues in pollen loads collected by honey bees in France. J. Econ. Entomol. 99, 253-262.

Chen, K.T., Malo, M.S., Beasley-Topliffe, L.K., Poelstra, K., Millan, J.L., Mostafa, G. Alam, S.N., Ramasamy, S., Warren, H.S., Hohmann, E.L., Hodin, R.A., 2011. A role for intestinal alkaline phosphatase in the maintenance of local gut immunity. Dig. Dis. Sci. 56, 1020-1027.

Chuang, D.M., Hough, C., Senatorov, V.V., 2005. Glyceraldehyde-3-phosphate dehydrogenase, apoptosis and neurodegenerative diseases. Annu. Rev. Pharmacol Toxicol. 45, 269-290.

Coleman, J., 1992. Structure and mechanism of alkaline phosphatase. Annu. Rev Biophys. Biomol. Struct. 21, 441-483.

Colin, M.E., Belzunces, L.P., 1992. Evidence of synergy between prochloraz and deltamethrin in Apis mellifera L: a convenient biological approach. Pestic. Sci. 36, 115-119.

Decourtye, A., Lefort, S., Devillers, J., Gauthier, M., Aupinel, P., Tisseur, M., 2009. Sublethal effects of fipronil on the ability of honeybees (Apis mellifera L.) to orientate in a complex maze. Julius-Kuhn Archiv 423, 75-83.

Desneux, N., Decourtye, A., Delpuech, J.M., 2007. The sublethal effects of pesticides on beneficial arthropods. Annu. Rev. Entomol. 52, 81-106.

Di Pasquale, G., Salignon, M., Le Conte, Y., Belzunces, L.P., Decourtye, A., Kretzschmar, A., Suchail, S., Brunet, J.-L., Alaux, C., 2013. Influence of pollen nutrition on honey bee health: do pollen quality and diversity matter? Plos One 8, 72016.

Duan, J.J., Marvier, M., Huesing, J., Dively, G., Huang, Z.Y., 2008. A meta-analysis of effects of Bt crops on honey bees (Hymenoptera: Apidae). PLoS One 3, 6.

Dulmage, H.T., 1970. Insecticidal activity of HD-1, a new isolate of Bacillus thuringiensis var. alesti. J. Invertebr. Pathol. 15, 232-239.

Dussaubat, C., Brunet, J.-L., Higes, M., Colbourne, J.K., Lopez, J., Choi, J.H., MartinHernandez, R., Botias, C., Cousin, M., Mcdonnell, C., Bonnet, M., Belzunces, L.P., Moritz, R.F.A., Le Conte, Y., Alaux, C., 2012. Gut pathology and responses to the microsporidium Nosema ceranae in the honey bee Apis mellifera. PLoS One 7, 11

da Silva Cruz, A., da Silva-Zacarin, E.C., Bueno, O.C., Malaspina, O., 2010. Morphological alterations induced by boric acid and fipronil in the midgut of worker honeybee (Apis mellifera L.) larvae. Cell Biol. Toxicol. 26, 165-176.

El Hassani, A.K., Dacher, M., Gauthier, M., Armengaud, C., 2005. Effects of sublethal doses of fipronil on the behavior of the honeybee (Apis mellifera). Pharmacol. Biochem. Behav. 82, 30-39.

European Food Safety Authority (EFSA), 2012. Conclusion on the peer review of the pesticide risk assessment of the active substance Bacillus thuringiensis subsp. kurstaki (strains ABTS 351, PB 54, SA 11, SA 12, EG 2348). Eur. Food Saf. Auth. J 2012 (10), 66.

Evans, J.D., Lopez, D.L., 2004. Bacterial probiotics induce an immune response in the honey bee (Hymenoptera: Apidae). J. Econ. Entomol. 97, 752-756.

Gill, S.S., Cowles, E.A., Pietrantonio, P.V., 1992. The mode of action of Bacillus thuringiensis endotoxins. Annu. Rev. Entomol. 37, 615-636.

Gonzàlez, J.M.J., Brown, B.J., Carlton, B.C., 1982. Transfer of Bacillus thuringiensis plasmids coding for S-endotoxin among strains of $B$. thuringiensis and B. cereus. 
Proc. Natl. Acad. Sci. USA 79, 6951-6955.

Grant, C., 2008. Metabolic reconfiguration is a regulated response to oxidative stress. J. Biol. 7, 1.

Habig, W.H., Pabst, M.J., Jakoby, W.B., 1974. Glutathione S-transferases. The first enzymatic step in mercapturic acid formation. J. Biol. Chem. 249, 7130-7139.

Han, P., Chang-Ying, N., Chao-Liang, L., Jin-Jie, C., Desneux, N., 2010. Use of an innovative T-tube maze assay and the proboscis extension response assay to assess sublethal effects of GM products and pesticides on learning capacity of the honey bee Apis mellifera L. Ecotoxicology 19, 1612-1619.

Ikeda, T., Zhao, X., Kono, Y., Yeh, J.Z., Narahashi, T., 2003. Fipronil modulation of glutamate-induced chloride currents in cockroach thoracic ganglion neurons. Neurotoxicology 24, 807-815.

Iwasa, T., Motoyama, N., Ambrose, J.T., Roe, R.M., 2004. Mechanism for the differential toxicity of neonicotinoid insecticides in the honey bee, Apis mellifera. Crop Prot. 23, 371-378.

Kletzien, R.F., Harris, P.K., Foellmi, L.A., 1994. Glucose-6-phosphate dehydrogenase: a housekeeping enzyme subject to tissue-specific regulation by hormones, nutrients, and oxidant stress. FASEB J. 8, 174-181.

Krupke, C.H., Hunt, G.J., Eitzer, B.D., Andino, G., Given, K., 2012. Multiple routes of pesticide exposure for honey bees living near agricultural fields. PLoS One 7. 29268.

Leaver, M.J., George, S.G., 1998. A piscine glutathione S-transferase which efficiently conjugates the end-products of lipid peroxidation. Mar. Environ. Res. 46, 71-74.

Maini, S., Medrzycki, P., Porrini, C., 2010. The puzzle of honey bee losses: a brief review. Bull. Insectol. 63, 153-160.

Malone, L.A., Burgess, E.P.J., Stefanovic, D., 1999. Effects of a Bacillus thuringiensis toxin, two Bacillus thuringiensis biopesticide formulations, and a soybean trypsin inhibitor on honey bee (Apis mellifera L.) survival and food consumption. Apidologie 30, 465-473.

Mommaerts, V., Jans, K., Smagghe, G., 2010. Impact of Bacillus thuringiensis strains on survival, reproduction and foraging behaviour in bumblebees (Bombus terrestris). Pest Manag. Sci. 66, 520-525.

Morales-Rodriguez, A., Peck, D.C., 2009. Synergies between biological and neonicotinoid insecticides for the curative control of the white grubs Amphimallon majale and Popillia japonica. Biol. Control 51, 169-180.

Mullin, C.A., Frazier, M., Frazier, J.L., Ashcraft, S., Simonds, R., vanEngelsdorp, D., Pettis, J.S., 2010. High levels of miticides and agrochemicals in North American apiaries: implications for honey bee health. PLoS One 5, 9754.

Narahashi, T., Zhao, X., Ikeda, T., Salgado, V.L., Yeh, J.Z., 2010. Glutamate-activated chloride channels: unique fipronil targets present in insects but not in mammals. Pestic. Biochem. Physiol. 97, 149-152.

Nicholls, C., Li, H., Liu, J.P., 2012. GAPDH: a common enzyme with uncommon functions. Clin. Exp. Pharmacol. Physiol. 39, 674-679.

Ortiz-Ortiz, M.A., Moran, J.M., Ruiz-Mesa, L.M., Pedro, J., Fuentes, J.M., 2010. Paraquat exposure induces nuclear translocation of glyceraldehyde-3-phosphate dehydrogenase (GAPDH) and the activation of the nitric oxide-GAPDH-siah cell death cascade. Toxicol. Sci. 116, 614-622.

Pareja, L., Colazzo, M., Perez-Parada, A., Niell, S., Carrasco-Letelier, L., Besil, N., Cesio, M.V., Heinzen, H., 2011. Detection of pesticides in active and depopulated beehives in Uruguay. Int. J. Environ. Res. Public Health 8, 3844-3858.

Potts, S.G., Biesmeijer, J.C., Kremen, C., Neumann, P., Schweiger, O., Kunin, W.E., 2010. Global pollinator declines: trends, impacts and drivers. Trends Ecol. Evol. 25, 345-353.

Ramirez-Romero, R., Chaufaux, J., Pham-Delègue, M.H., 2005. Effects of Cry1Ab protoxin, deltamethrin and imidacloprid on the foraging activity and the learning performances of the honeybee Apis mellifera, a comparative approach. Apidologie 36, 601-611.

Ramirez-Romero, R., Desneux, N., Decourtye, A., Chaffiol, A., Pham-Delègue, M.H. 2008. Does CrylAb protein affect learning performances of the honey bee Apis mellifera L. (Hymenoptera, Apidae)? Ecotox. Environ. Saf. 70, 327-333.

Rortais, A., Arnold, G., Halm, M.-P., Touffet-Briens, F., 2005. Modes of honeybees exposure to systemic insecticides: estimated amounts of contaminated pollen and nectar consumed by different categories of bees. Apidologie 36, 71-83.

Sheehan, D., Meade, G., Foley, V.M., Dowd, C.A., 2001. Structure, function and evolution of glutathione transferases: implications for classification of nonmammalian members of an ancient enzyme superfamily. Biochem. J. 360, 1-16.

Singh, S.K., Mathur, Y.K., Yadav, D.K., 2007. Efficacy of Bt with insecticides against Mythimna separata. Ann. Plant Prot. Sci. 15, 239-240.

Sirover, M.A., 2005. New nuclear functions of the glycolytic protein, glyceraldehyde-3-phosphate dehydrogenase, in mammalian cells. J. Cell. Biochem. 95, $45-52$.

Suchail, S., De Sousa, G., Rahmani, R., Belzunces, L.P., 2004. In vivo distribution and metabolisation of C-14-imidacloprid in different compartments of Apis mellifera L. Pest Manag. Sci. 60, 1056-1062.

Sudhakar, K., Dhingra, S., 2002. Effect of combinations of sublethal concentrations of chemical and microbial insecticides to different larval instars of Spodoptera litura (Fabricius). Pestic. Res. J. 14, 32-39.

Upadhyay, S.K., Singh, P.K., 2011. Role of alkaline phosphatase in insecticidal action of Cry1Ac against Helicoverpa armigera larvae. Biotechnol. Lett. 33, 2027-2036.

Vachon, V., Laprade, R., Schwartz, J.L., 2012. Current models of the mode of action of Bacillus thuringiensis insecticidal crystal proteins: a critical review. J. Invertebr. Pathol. 111, 1-12.

Van Der Zee, R., Pisa, L., Andonov, S., Brodschneider, R., Charrière, J.-D., Chlebo, R., Coffey, M.F., Crailsheim, K., Dahle, B., Gajda, A., Gray, A., Drazic, M.M., Higes, M., Kauko, L., Kence, A., Kence, M., Kezic, N., Kiprijanovska, H., Kralj, J., Kristiansen, P., Hernandez, R.M., Mutinelli, F., Nguyen, B.K., Otten, C., Ozkirim, A., Pernal, S.F., Peterson, M., Ramsay, G., Santrac, V., Soroker, V., Topolska, G., Uzunov, A., Vejsnaes, F., Wei, S., Wilkins, S., 2012. Managed honey bee colony losses in Canada, China, Europe, Israel and Turkey, for the winters of 2008-9 and 200910. J. Apic. Res. 51, 100-114.

vanEngelsdorp, D., Hayes, J.J., Underwood, R.M., Pettis, J., 2008. A survey of honey bee colony losses in the U.S., Fall 2007 to Spring 2008. PLoS One 3, 4071

Verma, R.S., Mehta, A., Srivastava, N., 2007. In vivo chlorpyrifos induced oxidative stress: attenuation by antioxidant vitamins. Pestic. Biochem. Physiol. 88, $191-196$.

Vidau, C., Brunet, J.-L., Badiou, A., Belzunces, L.P., 2009. Phenylpyrazole insecticides induce cytotoxicity by altering mechanisms involved in cellular energy supply in the human epithelial cell model Caco-2. Toxicol. Vitr. 23, 589-597.

Vidau, C., Diogon, M., Aufauvre, J., Fontbonne, R., Vigues, B., Brunet, J.-L., Texier, C., Biron, D.G., Blot, N., El Alaoui, H., Belzunces, L.P., Delbac, F., 2011. Exposure to sublethal doses of fipronil and thiacloprid highly increases mortality of honeybees previously infected by Nosema ceranae. PLoS One 6, 8 .

Vlahovic, M., Lazarevic, J., Peric-Mataruga, V., Ilijin, L., Mrdakovic, M., 2009. Plastic responses of larval mass and alkaline phosphatase to cadmium in the gypsy moth larvae. Ecotox. Environ. Saf. 72, 1148-1155.

Wiest, L., Bulete, A., Giroud, B., Fratta, C., Amic, S., Lambert, O., Pouliquen, H., Arnaudguilhem, C., 2011. Multi-residue analysis of 80 environmental contaminants in honeys, honeybees and pollens by one extraction procedure followed by liquid and gas chromatography coupled with mass spectrometric detection. J. Chromatogr. A 1218, 5743-5756.

Williams, G.R., Alaux, C., Costa, C., Csáki, T., Doublet, V., Eisenhardt, D., Fries, I., Kuhn, R., McMahon, D.P., Medrzycki, P., Murray, T.E., Natsopoulou, M.E., Neumann, P., Oliver, R., Paxton, R.J., Pernal, S.F., Shutler, D., Tanner, G., van der Steen, J.J.M., Brodschneider, R., 2013. Standard methods for maintaining adult Apis mellifera in cages under in vitro laboratory conditions. In: Dietemann, V., Ellis, J. D., Neumann, P. (Eds.), The COLOSS BEEBOOK, Volume I: Standard Methods for Apis mellifera Research. J. Apic. Res., vol. 52, 〈http://dx.doi.org/10.3896/IBRA.1. 52.1.04).

Wu, G., You, M., Zhao, S., Jiang, S., 2001. Synergism of Bacillus thuringiensis pretreatment to organophosphate and carbamate insecticides in Plutella xylostella. Acta Entomol. Sin. 44, 454-461. 